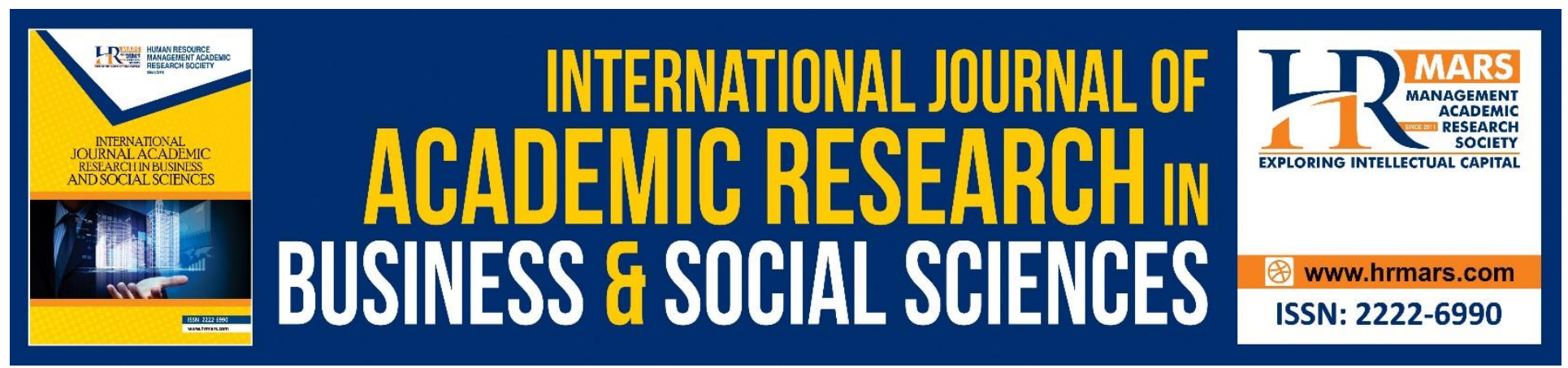

\title{
Implementation of Distributive Leadership into Teacher Competency Empowerment and Job Satisfaction
}

\author{
Yunus Mohamed Ali Fiah, Aida Hanim A. Hamid
}

To Link this Article: http://dx.doi.org/10.6007/IJARBSS/v10-i6/7461

DOI:10.6007/IJARBSS/v10-i6/7461

Received: 08 April 2020, Revised: 15 May 2020, Accepted: 18 June 2020

Published Online: 24 July 2020

In-Text Citation: (Fiah \& Hamid, 2020)

To Cite this Article: Fiah, Y. M. A., \& Hamid, A. H. A. (2020). Implementation of Distributive Leadership into Teacher Competency Empowerment and Job Satisfaction. International Journal of Academic Research in Business and Social Sciences, 10(6), 916-926.

Copyright: (c) 2020 The Author(s)

Published by Human Resource Management Academic Research Society (www.hrmars.com)

This article is published under the Creative Commons Attribution (CC BY 4.0) license. Anyone may reproduce, distribute, translate and create derivative works of this article (for both commercial and non-commercial purposes), subject to full attribution to the original publication and authors. The full terms of this license may be seen at: $\underline{\text { http://creativecommons.org/licences/by/4.0/legalcode }}$

Vol. 10, No. 6, 2020, Pg. 916 - 926

http://hrmars.com/index.php/pages/detail/IJARBSS

JOURNAL HOMEPAGE

Full Terms \& Conditions of access and use can be found at http://hrmars.com/index.php/pages/detail/publication-ethics 


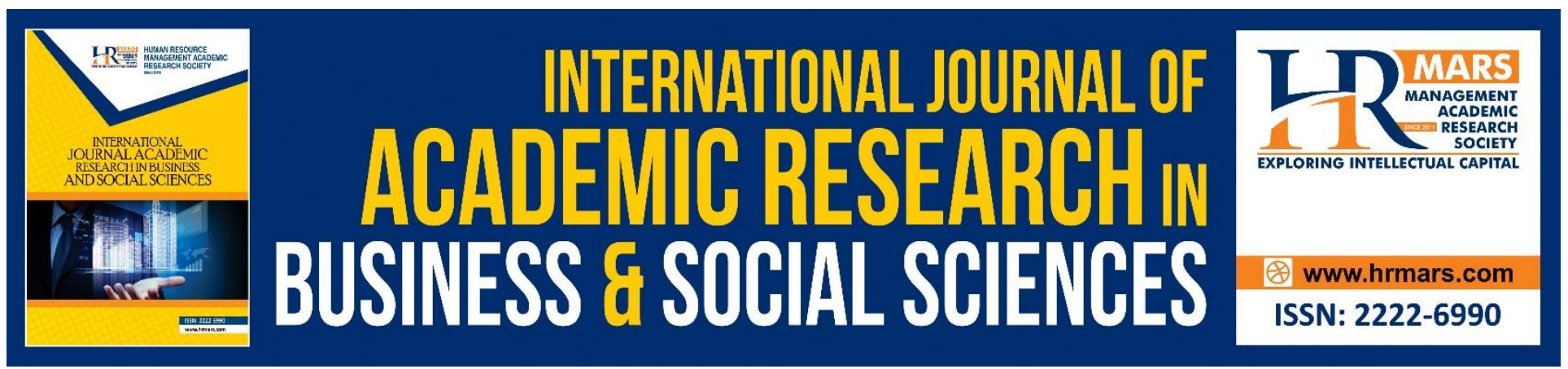

\title{
Implementation of Distributive Leadership into Teacher Competency Empowerment and Job Satisfaction
}

\author{
Yunus Mohamed Ali Fiah, Aida Hanim A. Hamid \\ Faculty of Education, The National University of Malaysia, 43600 Bangi, Selangor. \\ Email: yunusmelati@gmail.com
}

\begin{abstract}
The leadership of the school headmasters play a very significant role in creating a conducive climate for elevating school excellence to the highest level. To this end, this concept paper examines the practice of distributive leadership practices, the empowerment of teachers, and the satisfaction of working among schoolchildren to realize such excellence. The school excellence is often expressed in the absence of the headmaster's style of leadership as a school leader. The distributive leadership is a form of collective leadership that empowers subordinates. This concept paper emphasizes the role played by the headmasters in efforts to enhance the teachers' competence in the areas of strategic thinking, dynamic leadership, systematic work culture and futuristic thinking and to create an atmosphere of schoolwork. The pursuit of such competencies is expected to help school management implement planning and achieve its mission and vision more effectively. In addition, the inputs and discussions of recent studies on these elements and their sequences are also been discussed. It is hoped that the three elements discussed will serve as a guide for the headmasters in mobilizing the whole school to achieve inclusive excellence.
\end{abstract}

Keywords: Distributive Leadership, Teacher Competence, Strategic Thinking, Dynamic Leadership, Systematic Work Culture, Futuristic Thinking and Job Satisfaction.

\section{Introduction}

The former Malaysian Education Director-General, Datuk Dr Amin Senin wish to incorporate the quality schools and students inclusion is a challenge for the educators. This will be achieved if the leadership style of the headmasters is accepted by the teachers, the development of teacher competence and the satisfaction of working with the school staff. Many think that the school performance begins with the leadership style of a principal or a headmaster as the main driving factor. The transition to the practice of distributive leadership among the headmasters is one of the elements that make this idea possible. The distributive leadership is one that embraces another aspect of popular leadership theory (Harun et al., 2016). Thus, distributive leadership can be known 
INTERNATIONAL JOURNAL OF ACADEMIC RESEARCH IN BUSINESS AND SOCIAL SCIENCES Vol. 10, No. 6, June, 2020, E-ISSN: 2222-6990 @ 2020 HRMARS

as multiple leaders (Spillane et al., 2004). The distributive leadership style allows the headmasters to share the increasing burden of work with subordinates (Tian et al., 215).

There is no denying that the past studies have shown that a principal or a headmaster is at the heart of school success (Harris, 2009; Mahmud, 1993; Ahmad, 2012; Leithwood and Jantzi, 1999; Ofsted, 2000; Ministry of Education, 2013; Sergiovanni, 2000). Ubben and Hughes (1997) and Drake and Roe (1999) have stated that everything that happens in the school is the responsibility of the principal and they need to create a school climate to be conducive to the teachers, students and the learning process. However, based on recent empirical information, it is found that the school duties and responsibilities can no longer be assigned to the principals or headmasters alone, but their connotations need to be shared partly with other teachers too.

The distributive leadership style (shared) of the headmasters interpret the willingness to share power and to co-opt decision-making together. They are no longer alone in making all the decisions related to the school. It goes with the opinion of Rosnarizah and Hussein (2015) that today's educational leadership has changed and no longer sees that the principals taking on all responsibilities as leaders in an effort to improve school performance. In addition, the leadership should be appropriate with the needs and demands (Harris \& Spillance, 2008; Harris, 2008; Harris, 2012).

The teachers really play a role in the quality of school and student self-advocacy as outlined in the book 'Melangkah Ke Hadapan'. The success in bringing these two elements together is synonymous with the satisfaction of working among the teachers in schools. The satisfaction of working for teachers will produce better quality work and they will always have more time to do the work in the school. Therefore, matters related to the enjoyment or satisfaction of working among the teachers needs to be addressed with great care and concern for the school leaders. Based on Oshagbemi (2003), work happiness is an important attribute that every organization wants to achieve. This statement support the opinion by Robbin (2001) which says there is significant evidence that dissatisfied workers are more likely to drop out and have potentially destructive behaviors. This is a hindrance to the school's image of inclusive excellence. The implementation of the school leadership (distributive) style and continuous improvement of the teachers' competence are believed to be able to assess their satisfaction and thus impact for the school success.

In addition, the teacher leadership competence in the school is also very important to polish and develop. This is because we need to be acknowledged that in some of the key areas of leadership in schools, the teachers prefer to receive instructions from their peers than the direct instructions from the headmasters.

However, it is not easy for most of the headmasters to implement it unless they are truly competent with various branches of management knowledge and are exposed to various theories and leadership models. In this regard the proposal, the Ministry of Education to place the high performing leaders as headmasters or school principals through the launched of Malaysia Education Blueprint 2013-2025 in the fifth shift was a great action.

Education is the most important agenda for any government in the world. They always upgrade the transition for a better level in order to be the best in this field. The changes in all always happen based on every aspect including from the basic and the system itself. More fundamental change is the leadership style practiced in schools that will have a profound impact on the organization. The teachers whom as a group to implement the educational policies implemented in schools need to work on their competencies. In this regard, this conceptual paper addresses the 
INTERNATIONAL JOURNAL OF ACADEMIC RESEARCH IN BUSINESS AND SOCIAL SCIENCES

Vol. 10, No. 6, June, 2020, E-ISSN: 2222-6990 @ 2020 HRMARS

capacity building of teachers that also impacts on job satisfaction for them. Both of these elements are related to the leadership style of the headmaster in managing the organization. The headmasters should therefore strive to apply the distributive model as it fits with the changing and waqi '(reality) of the school organization and the idealism of today's teachers.

\section{Distributed Leadership in a Contractive Change Context}

Distributive leadership is a concept that emerged in the early 2000s from a combination of existing sociological, cognitive, psychological and anthropological theories (Hermann, 2016). Previously, democratic, autocratic and laissez faire leadership models colored school education leadership. The distributive leadership model began to take over the leadership style in schools and was seriously practiced in our country starting in 2009 during the National Procedure Seminar and 16 Leadership Education organized by the Institut Aminuddin Baki (IAB) by the theme of 'Distributed Leadership'( Marlia \& Yahya, 2016).

The distributive leadership is a framework of thinking that encourages more individuals to engage in formal or informal leadership (Spillane, 2006). The distributive leadership is a leadership that ben shared with the group of members for the benefits of the organization (Angelle, 2010). This leadership model means that the leaders in any organization need to be open-minded and always ready to delegate power according to the level and strata of the organization to other subordinates. At stake in dissociative leadership is the belief and recognition of all aspects of leadership, that they are also capable of realizing their tasks in line with the planned plans.

However, based on Dinham, Aubussion and Bradly (2006) opinion, there is a slightly different that distributive leadership is an aspect of development that supports, encourages and empowers employees rather than delegates the power of individuals to take on new leadership roles. The distributive leadership is a sharing practice between the leader, followers and situation in the organization. It integrates the activities of the entire group of individuals within the school by mobilizing and guiding the whole school through examples of leadership practices. This explains that it is a function of the distribution or distribution of functions in which several individuals accomplish tasks through interaction. It is literal and less hiraki in the staff function (Harris \& Spillane, 2008).

The main focus for this concept paper is how far the willingness of the headmasters to share parts of their leadership with the senior teachers and teachers also their readiness to adapt the syura in decision making. Based on the statement, the headmasters are not alone to make any school decisions.

\section{Teacher Competence Development}

In the era of the knowledge-based economy, the Malaysian government has taken steps to introduce competency models as one of the enhancements in the management of human services, including education. Based on the bilingual dictionary by Dewan, kompetensi is a term borrowed from the English word competence, which means speed, willingness and efficiency to perform a task (Dewan Bahasa dan Pustaka, 1999). Bayaitzis (2001), Ayob (2007), Shell (1995), and Nordhaugl and Grouhaug (1994) defined competence as the basic skills that relate with the effective or ability to do tasks. Meanwhile, Ibrahim (2000) explained that competence means the combination of knowledge, skills and personal traits that anyone should have and been practiced in order to do any work or post.

Brian et al. (2000) defined competence as knowledge, membership, ability or personal knowledge that affecting the work success. The teachers' competences that need to be attention 
INTERNATIONAL JOURNAL OF ACADEMIC RESEARCH IN BUSINESS AND SOCIAL SCIENCES

Vol. 10, No. 6, June, 2020, E-ISSN: 2222-6990 @ 2020 HRMARS

through this concept paper are the strategic development, systematic, futuristic, and dynamics between the teachers especially the senior teachers and the teachers that have the skills in leadership.

\section{Strategic Value, Dynamics, Systematic and Futuristic}

The headmasters can practice the effective leadership if they have strategic thinking, dynamic, systematic and high futuristic and need to keep on guiding their teachers to apply the values. Thinking is the nucleus that control and drive any actions including in the leadership aspect (Yusri, 2019). So, based on him, the headmasters must always guide their teachers to have and to apply the way of thinking as a way to develop the school inclusively.

According to Yusri (2019), the headmasters effort to make sure that the empowerment of strategic thinking between teachers through these ways :

i. Providing examples does not make the action unreasonable and clear. Predictions must be founded on the support of empirical information and sound judgment.

ii. Defining and operationalizing the goals that the school intends to achieve, providing a strategic plan before all matters begin.

iii. Willing to accept failure as part of the management process and a process for achieving school excellence.

Meanwhile, in an attempt to deceive futuristic thinking, among other things, try to guide teachers for :

i. $\quad$ Provide students with relevant knowledge for future needs.

ii. Explore new high-impact ideas and approaches to school leadership.

iii. Set clear vision for the future school achievements.

In order to apply for the systematic and dynamic values to teachers, the headmaster

should practice the following :

i Transition of power to their workforce to make decisions thus maximizes productivity.

ii. Reduces the time wasted for meetings and delivery processes.

iii. Establish the clear job guidance and objective outcome expectations.

iv. Create a culture of continuous learning in the organization (Mark, 2016), specifically to make the school as a learning organization (learning organization), it is not as just a teaching institution that focuses solely on teaching students.

All of the above elements require constant guidance and confidence from the headmasters over all the teachers. This value also takes time to become a culture or habit that enhances teachers' competence.

\section{Job Satisfaction}

Although the studies of job satisfaction have been widely conducted, but the job and the work environment are constantly changing, so the issues of job satisfaction are always important to address. Rinehort and Shotr (1994) said that there is always a need to explore the relationship between psychological constructs such as motivation and job satisfaction that may influence and influence the school climate. Job satisfaction by interpretation of Greenberg (2000), refers to the affective reactions of individuals (e.g. happy or unhappy) to specific aspects of the work performed such as the job itself, salary, supervision, promotion, and co-workers. The job satisfaction is also associated with an affective or emotional aspect of a person's work or work experience. 
INTERNATIONAL JOURNAL OF ACADEMIC RESEARCH IN BUSINESS AND SOCIAL SCIENCES

Vol. 10, No. 6, June, 2020, E-ISSN: 2222-6990 @ 2020 HRMARS

Oshagbemi (2003), stated that job satisfaction is an important attribute that every organization wants to achieve, and this statement is supported by Robbin (2001), which says there is significant evidence that dissatisfied workers are more likely to drop out and have potentially destructive behaviors. Meanwhile, Gordon (2002), job satisfaction results when a job fulfills one's values, hopes and goals and dissatisfaction occurs when a job is prevented from achieving those goals.

This concept paper argues that the job satisfaction is a positive emotion or happy emotion and that it can be manifested through the behavior of the job when the elements associated with the work environment are in line with what is desired from the job. The factors of trust and devotion by the headmaster to the teachers are very insightful and help to create a conducive working atmosphere. Therefore, it is clear that job satisfaction in this study is summarized as teachers' feelings towards their profession, to the extent that teachers are happy or not at work and work environment including tasks and responsibilities.

\section{The Purpose of the Concept Paper}

The purpose of this concept paper is to illustrate the benefits of the leadership style of the distributive models that more value and trust in teachers' abilities and willingness to share power among headmasters. This style is preferred by the teachers because it is a syura method and values the ability of the teachers to play a role in decision making. The application of this style of leadership has the potential to influence the teachers' competencies and create an atmosphere of work satisfaction among the teachers, thus promoting the school excellence in every field.

\section{Sample and Discussion on Latest Study Distributive Leadership}

The headmaster plays a very significant role in managing change. McNulty, Waters \& Marzano (2005) said that the principal's role in the school was not limited to administrative the responsibilities but that he had to mobilize all kinds of resources under his supervision especially the teachers to serve committedly and effectively.

Gronn (2000) suggested that a distributive leadership approach gives one another power in school, the tendency for the followers and leaders to work together. The distributive leadership supports the centralization of leadership among teachers in schools. In this case, the leadership should be better understood that 'bending and reforming', it is better to change existing phenomena. Gronn (2000) explained that the view to an individual about a way or more ways to do the leadership. This does not mean that everyone is a leader, or should be, but it does provide an opportunity for a more democratic and collective form of leadership (Goleman, 2002). Leadership is a more collective phenomenon where "existing leadership is in the flow of activities with a group of organizational members who know they should be involved" (Gronn, 2000).

According to Dinham, Aubusson and Brady (2006), distributive leadership is an aspect of development that supports, encourages and empowers workers rather than delegates the power of individuals to take on new leadership roles. Distributive leadership is the practice of sharing between leaders, followers and situations within their organization. It integrates the activities of the entire group of individuals within the school by mobilizing and guiding staff through teaching leadership. This indicates that it is the dissemination or distribution of functions by which individuals achieve 
tasks through interaction. It is more lateral and less hierarchical in the way the staff works (Harris \& Spillane, 2008).

Although some studies on distributive leadership have been conducted in Malaysia, some researchers have concluded that studies of distributive importance are still in the early stages and it is suggested that more studies should be conducted (Rosnarizah \& Hussein, 2015).

\section{Enhancing the Teacher Competence}

In order to realize the desire to reach the quality schools and students inclusion inclusive of teacher competence should be given attention. The schools that have teachers of various competencies will produce quality students in various fields. A researched by Yahaya, Hashim and Azizuddin about PPSMI concluded that the success of teaching and learning Science and Mathematics in English depends largely on teachers' ability to do so as teachers are the key agents in delivering and disseminating knowledge. So, the Science and Mathematics teachers must have high level of competence to do any tasks that been responsibilities on them. They have to be ready to move on based on the latest changes and suit with any situation and condition that they might be in the future. Based on that, every change that been introduce by the ministry must be follow by all he teachers and they need to understand and do it as good as they can. The teachers have to be responsible to every change that will happen in future.

Saad and Baharuddin (2016) explained that the implementation of the High School Standard Curriculum by the Ministry of Education on 2017 that applied the Higher Order Thinking Skills showed that the needed of the teachers to attend courses, training or proceed their education to another higher level as a way to make sure they have the latest knowledge in parallel with the new curriculum and be ready to face the pupils confidently. The teachers that have a higher competence level will be a good asset for the schools and the ministry either because they are going to face the pupils with the functional steadily to realize the excellent in education.

According to Rahman (1995), if the teachers want to build the quality pupils, they must be better than the pupils. This really show that how important is for the teachers to be competence to be a great teachers. Meanwhile, Ahmad (1996), the workforce and human resources need to be trained and enhanced in their knowledge and skills in order to make a world-class contribution.

\section{Job Satisfaction}

There were many research been done for the job satisfaction among the school community regarding the personality or management style focusing on the principles and headmasters that created the organization culture. Herzberg (1966) put the work place as the hygiene factor that push the workers to feel satisfy or not can affecting their job satisfaction. From this factor, the nicest and friendly working places totally affecting the job satisfaction. Sharing tasks and open minded of the headmasters in accepting the teachers' competence in doing their tasks can create the comfortable working places.

The leadership in any organizations becomes another factor to support the job satisfaction for the workers. The work attitude or the behavior of the headmasters and the senior teachers may affect the teachers indirectly. Based on Simon (1947), the workers can be obedient to the supervisors as long as the instructions are valid and reliable. Fiedler (1967), the effectiveness of a group depends on the leadership style of the leader in which the situation plays a role in enhancing the achievement, morale and job satisfaction of the group. 
The result from the research by Mc Neely (1983) showed that the workers that have a leader that lead the company with the staff relationship orientation may have the highest job satisfaction. The leaders that apply the openness and harmony attitude will get the respect by the staff and this can make their performance better. An atmosphere of communication between employees who respect and help each other and work together will increase the productivity.

\section{Implications of the Concept Paper}

Schools are the premise of making changes in the field of education in line with current needs. Changes in school education must be planned and involve the school as a whole. It also requires knowledge and skills that are in line with current needs. According to Izham \& Hussin (2009), change requires the learning of new knowledge and skills. Brainsden, Hilario and Massarella (2002) defoned that change as a conscious effort and intentionally towards a goal of improving the system.

This concept paper examines three key elements of change in the school - the leadership style (distributive), the promotion of teacher competence and the job satisfaction of the school population. Here are the three implications that will shape the school situation as a result of the implementation of this concept paper:

7.1 Distributive leadership is a leadership style that incorporates a wide variety of leadership styles the core of this leadership is the sharing of power (responsibility) and authority in decision making. Therefore, headmasters need to be open-minded, positive-thinking with the end of their power and their role in school.

These changes are important to smooth management tasks while reducing the burden of the headmasters. It is in line with the statement from Halim and Ahmad (2015) that today's educational leadership has changed and no longer sees the headmaster whom taking on all the responsibilities of being a leader as an effort to improve school performance. To make this change, the headmasters must be exposed to various distributive leadership workshops to avoid internal conflicts. Self-effort should also be made by the headmaster by increasing his readings on this style of leadership.

Self-effort should also be made by the headmaster by increasing his readings on this style of leadership. This is because the teachers including senior assistant teachers have been exposed to management responsibilities and leadership skills through the sharing of responsibilities and authority exercised by the headmaster. This will provide the best quality and performance for teachers through the school experience.

The practice of distributive leadership will foster a culture of trust between school leaders and teachers. This is done when the willingness of the headmaster shares some of his responsibilities with the senior assistant teachers or specific teachers. This transition of duty and responsibility can only occur if there is a teacher's trust in the teacher, and the teacher believes in being able to fulfill that responsibility. This will create an atmosphere of harmony within the organization as well as enhance the potential for leadership among teachers

The practice of distributive leadership of the headmaster will produce strong leadership in the school. This is because more leadership opportunities are provided for teachers to lead small units in schools. Leadership among teachers provides more opportunities for groups or teams to collectively fulfill specific school responsibilities, resources, and space to address problems in schools (Yahya, Mohamed \& Ghani, 2007). Sergiovani (2001) established that strong leadership means that more people are involved in a work, believed to have information, are involved in decision-making, have 
the opportunity to present new ideas and are involved in decision-making, have the opportunity to present new ideas and are involved in knowledge creation and transfer.

7.2 Most of the organizations have difficulty identifying and selecting the best individuals to hold the highest positions in schools (Razak, 2013). Therefore, investing in a variety of leadership development activities is important to ensure that the best individuals are ready to guide the school towards success (Muhyiddin Yassin, 2013). Therefore, the improvement of teacher competence through the guidance of the headmasters will create a highly competent teacher corrector for improving the quality of school and student incarceration. Mc Clelland and Rivai (2009) defines competence as a fundamental correction that a person possesses in the knowledge, skills, self-image, traits and motives that directly influence one's performance.

The effectiveness of competency-building is achieved after the headmasters incorporate strategic elements, systematic aspects and high precision, dynamically adapt to the situation, and place elements of futuristic future research on specific teachers. The effectiveness of competencybuilding is achieved after the headmasters incorporate strategic elements, systematic aspects and high precision, dynamically adapt to the situation, and place elements of futuristic future research on specific teachers.

7.3 The combination of the practice of distributive leadership of the headmasters and the promotion of teacher competence will create a fun working environment for the school community. By increasing the teachers' competency will accelerate the implementation of the workflow of competencies that have been developed within teachers from all areas of the school. The belief in teachers by the highest leadership creates a sense of self-esteem. Adhering to this feeling will encourage a higher work ethic among teachers.

\section{Conclusion}

It must be acknowledged that there is no perfect leadership model that can solve all the management problems at school. The need for a comprehensive literature reference and leadership model is essential for school leaders' guidance. Nowadays, the model of distributive leadership is believed to be best applied in light of the variety of elements that underlie school culture. The distributive leadership is the fundamental to change management in schools. The development of teacher competence is very important in the development of human resources in schools. The combination of these two elements is believed to create a sense of satisfaction within the school community. As a result, the desire to realize quality schools and student inclusion is easier to achieve.

\section{Corresponding Author}

Aida Hanim A. Hamid

Faculty of Education, The National University of Malaysia, 43600 Bangi, Selangor. aidahanim@ukm.edu.my

\section{References}

Dinham, S., Aubusson, P., \& Brady, L. (2006). Distributed leadership through action learning, keynote address, Fifth International Conference on Educational Leadership, Australian Centre for Educational Leadership. University of Wollongong. 16-17 February.

Goleman, D. (2002). The New Leaders: Transforming the Art of Leadership into the science of results. London, Little Brown. 
INTERNATIONAL JOURNAL OF ACADEMIC RESEARCH IN BUSINESS AND SOCIAL SCIENCES

Vol. 10, No. 6, June, 2020, E-ISSN: 2222-6990 @ 2020 HRMARS

Gronn, P. (2000). Distributed properties: A new architecture for leadership. Educational Management and Administration, 28(3), 317-338.

Halim, R. A. (2014). Kepemimpinan Distributif, Faktor Kontekstual Dan Efikasi Kendiri Guru Di Malaysia (Unpublished Doctoral Thesis) Universiti Malaya, Kuala Lumpur.

Harris, A. (2008). Distributed leadership: According to the evidence. Journal of Educational Administration, 46 (2), 172-188.

Harris, A. (2009). Distributed leadership: what we know. Dordrecht: Springer.

Harris, A., \& Spillance, J. (2008). Distributed leadership through looking glass. Management in Education BELMAS, 22 (1), 31-34.

Harris. A. (2012). Distributed leadership : Implications for the role of principal. Journal of Management Development, 31(1), 7-17.

Harun, A., Basri, R., Pihie, Z. A. L., \& Asimiran, S. (2016). International Journal of Education and Training (InjET), 2(2), 1- 13.

Ahmad, H. (2012). Mission of public education in Malaysia: the challenge of transformation. Kuala Lumpur: University of Malaya Press.

Ibrahim, M. A. (2000). Pendidikan dan pelatihan. Ilmu dan aplikasi pendidikan. Handbook.Bandung: Pedagogiana Press.

Jamail, M., \& Don, Y. (2016). Praktis Kepimpinan Distributif dan Komitmen Terhadap Organisasi Berdasarkan Kohort Generasi Guru. International Seminar on Generating Knowledge Through Research, UUM-UMSIDA, 25-27 October 2016, Universiti Utara Malaysia, Malaysia.

Jantan, A. (2007). Pengetua sekolah yang aktif. Cet. Ke-3. Kuala Lumpur: PTS Profesional Publishing Sdn. Bhd.

Kementerian Pendidikan Malaysia. (2013). Pelan Pembangunan Pendidikan Malaysia 2013 - 2025. Putrajaya: KPM.

Leithwood, K., \& Jantzi, D. (1999). Transformational school leadership effects: A reproduction. School Effectiveness and School Improvement, 10(4), 451 - 479.

Mahmud, H. (1993). Kepemimpinan Keberkesanan Sekolah. Kuala Lumpur: DBP.

McNulty, B., Waters, T., \& Marzano, R. (2005). School leadership that works: from research to results. Virginia: Association for Supervision and Curriculum Development.

Pelan Pembangunan Pendidikan Malaysia 2013-2025. (2013). Utusan

Online.http://www.utusan.com.my/utusan/Dalam_Negeri/20130907/dn_01/TPM-lancarPPPM-2013-2025

Teks ucapan sambutan Hari Pekerja. (2013).

http://www.mampu.gov.my/documents/10228/95706/Teks+ucapan+YAB+PM+sempena+Ha ri+Pekerja+1+Mei+2013.pdf/a8f2c6f2-149c-45d0-9b4b-897ee3ec78d

Ofsted. (2000). Improving City Schools. London: Office for Standard in Education.

Oshagbemi, T. (2003). Personal correlates of job satisfaction: empirical evidence from UK

Rinehart, J. S., \& Shotr, P. M. (1994).Job satisfaction and empowerment among teacher leaders, reading recovery teacher and regular classroom teacher. Journal of Education, 144.

Robbins, S. P. (2001). Organizational Behavior, (9th ed). New Jersey: Prentice Hall.

Rosnarizah \& Hussein. (2015). Kepimpinan Distributif, Faktor Kontekstual dan Efikasi Kendiri Guru di Malaysia. Jurnal Kepimpinan Pendidikan, 2(4). 
INTERNATIONAL JOURNAL OF ACADEMIC RESEARCH IN BUSINESS AND SOCIAL SCIENCES

Vol. 10, No. 6, June, 2020, E-ISSN: 2222-6990 @ 2020 HRMARS

Rutherford, C. (2009). Distributed Leadership and Comprehensive School Reform: Using the Distributed Perspective to Investigate the Distribution of Teacher Leadership. International Journal of Teacher Leadership ,2(2).

Sergiovanni T. J. (2000). The Lifeworld of Leadership: Creating culture, community, and personal meaning in our schools. San Francisco, CA: Josey-Bass Publishers.

Sergiovanni, T. J. (2001). Leadership: What 's in it for schools?. London, UK: Routledge.

Shakir, F. J., Isa, J. H., \& Mustafa, P. O. (2011). Perception towards distributed leadership in school improvement. International Journal of Business and Management, 6(10). doi: 10.5539/ijbm.v6n10p256

Spillane, H., \& Diamond. (2004). Towards a theory of leadership practice: a distributed perspective. Journal of Curriculum Studies, 36(1), 3-34. universities. International Journal of Social Economics, 30, 1210-1232.

Yahya, A. S., Mohammed, A. R., \& Abdullah, A. G. (2007). Guru sebagai pemimpin. Selangor. PTS Professional Publishing Sdn. Bhd.

Yusoff, Z. J. M., Don, Y., \& Ismail, S. N. (2014). Kompetensi Emosi Pemangkin Keberkesanan Amalan Kepimpinan Guru. Jurnal Kepimpinan Pendidikan. Dimuat turun daripada http://ejournal.um.edu.my/publish/JuPiDi/. 